\section{Introducing Machine Translation in the Translation Classroom: A Survey on Students' Attitudes and Perceptions}

\author{
Diana González Pastor
}

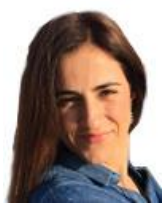

González Pastor, Diana Universitat de València diana.gonzalez@uv.es; ORCID: 0000-0002-4025-297X

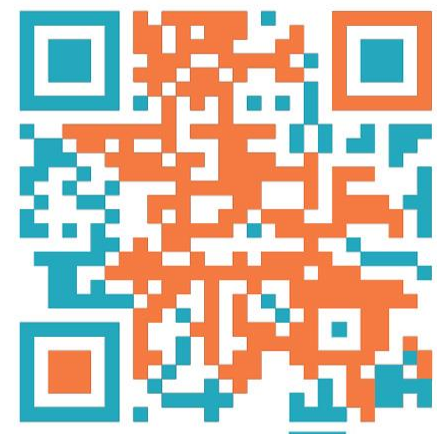

revista.trädumàtica

Abstract

The translation sector is going under major changes that will undoubtedly be accentuated in the future owing to the development of automation and artificial intelligence, and more specifically, of machine translation. Technology also plays a crucial role in the translation process and has a significant impact on translation competence. Therefore, it is of utmost importance that university translation programmes incorporate new translation technology into their curriculums in order to ensure that students are made aware of their usefulness in order to fulfil industry employment needs. This piece of research strives at mapping how and what for translation students use MT, and what are their attitudes and perceptions towards its use. Findings of a qualitative analysis indicate that undergraduate students have a positive general attitude towards MT and its many advantages, whereas they show preoccupation when MT professional issues are addressed.

Keywords: machine translation, students' attitudes and perceptions, qualitative research, thematic analysis, translation didactics

Resum

El sector de la traducció està experimentant grans canvis que, sens dubte, s'accentuaran en el futur gràcies al desenvolupament de l'automatització i la intel-ligència artificial $i$, més concretament, a la traducció automàtica. La tecnologia també juga un paper crucial en el procés de traducció i té un impacte significatiu en la competència traductora. Per això, és importantíssim que els programes de traducció incorporin noves tecnologies per tal de garantir que els estudiants prenguin consciència de la seva utilitat a l'hora de satisfer les necessitats laborals del sector. Aquest treball prova de determinar com i per què els estudiants de traducció fan servir la TA, i quina és la conducta i la percepció respecte al seu ús. Els resultats d'una anàlisi qualitativa indiquen que els estudiants de grau tenen una actitud generalment positiva cap a la TA i els nombrosos avantatges que ofereix, però que es mostren preocupats quan aborden els problemes professionals associats. 
Paraules clau: traducció automàtica, didàctica de la traducció, conducta i percepció dels estudiants, recerca qualitativa, anàlisi temàtica

Resumen

El sector de la traducción está experimentando grandes cambios que, sin duda alguna, se acentuarán en el futuro gracias al desarrollo de la automatización y la inteligencia artificial y, más concretamente, a la traducción automática. La tecnología también desempeña un papel crucial en el proceso de traducción y tiene un impacto significativo en la competencia traductora. Por eso, es importantísimo que los programas de traducción incorporen nuevas tecnologías para garantizar que los estudiantes sean conscientes de su utilidad a la hora de satisfacer las necesidades laborales del sector. Este trabajo intenta determinar cómo y por qué motivo los estudiantes de traducción utilizan la TA, y cuál es la conducta y la percepción respecto a su uso. Los resultados de un análisis cualitativo indican que los estudiantes de grado tienen una actitud generalmente positiva hacia la TA y sus numerosas ventajas, pero que se muestran preocupados cuando abordan los problemas profesionales asociados.

Palabras clave: traducción automàtica, didàctica de la traducción, conducta y percepción de los estudiantes, investigación cualitativa, anàlisis temática

\section{Introduction}

Today translation industry is growing fast at a global scale (De Palma et al., 2016). According to Pielmeier and O'Mara (2020), translation industry turnover has been growing steadily for the past decade and has almost doubled to reach 49.6 billion dollars in 2019. Language Service Providers (LSP) have to respond to the enormous volume of translation required by companies operating in different markets in need of speed and productivity. To support this growth, LSP are extending their repertoire beyond basic translation, localization, and interpreting to embrace their clients' global content strategy. The unstoppable advance of machine translation (MT) in recent years and the quality increase of its output has brought the introduction and spreading of this resource in more professional contexts "as it becomes integrated in widely used translation memory systems" (Koponen, 2016: 132). Actually, a large number of computer-assisted translation (CAT) tools already integrate neural machine translation (NMT), and it is likely that these engines will be a fundamental part of CAT environments in the short term. This technological progression, coupled with the popularization of MT, has had an impact not only on the translator's daily work and professional activities, but also on the working conditions of translators and their social standing (Díaz Fouces, 2019; Olohan, 2019), which have changed considerably. As a result, postediting (PE) arises as an emerging trend in the human translation workflow (Leiva Rojo, 2018) that will eventually become the usual practice within companies (Torres Hostench et al., 2016; Álvarez Vidal et al. 2020). As MT can also widen and diversify quality expectations (Way, 2018), price and productivity have also become essential factors (do Carmo, 2020; Vieira, 2020). 
In light with this new landscape in the translation sector (Gambier, 2014), extensive research is needed on the use of technology as a key instrument in the training of future translators and interpreters. A teaching experiment ${ }^{1}$ has been conducted in multiple courses across the curriculum of the Degree in Translation and Interlinguistic Mediation at the Universitat de València in Spain taking Mellinger's proposal as a framework (2017), whereby the teaching of technology and the incorporation of MT and $P E$ in the classroom is embedded transversally within the regular curriculum.

This paper first reviews previous literature on the subject. Second, it describes the MT teaching experiment and the research method. Finally, the paper provides the findings from a thematic analysis aimed at mapping the attitudes and perceptions from undergraduate students towards MT and draws conclusions that may contribute to open future paths for research in the teaching of MT in the translation classroom.

\section{The Didactics of Technology and MT}

Digitization and the advancement of translation technologies is pushing the industry towards a remarkable level of maturity (Díaz Fouces, 2019). The increasing integration of technology in the translator's workflow is altering the traditional role of translator. Even notions and terms like "translator" and "text" are being questioned and need to be reconfigured (Pym, 2011, 2013), as the so called "source" and "target" texts are now replaced by a "start text" that is "complemented by source materials that take shape of authorized translation memories, glossaries, terminology bases and machine-translation feeds" (Pym, 2013: 487). As the translator's productivity can increase when using MT (Sánchez Torrón, 2017; Zhechev, 2014), translators are being forced to change the skill sets required (Pym, 2013), while they claim to become each time more and more "word producers" instead of "text producers" (LeBlanc, 2017). Consequently, working conditions have also changed, as translators must charge their work differently depending on whether they are processing full or fuzzy matches, for example.

This changing landscape of the translation industry raises questions about the roles of humans and machines in the field (Koponen, 2016). In this connection, Rico (2017b) argues that MT should be part of an iterative cycle in which the translator has an essential role: far from the task of reviewing a product as a mere "operator", she becomes the "administrator" of the process (ibid. 2017b: 80). The new scenario also has significant implications in the didactics of translation. In response to the rapid changes in the language services industry, "translation educational programmes are integrating technology into curricula from different perspectives and contexts using particular tools and technologies" (Man et al., 2019: 254). Currently, there is much discussion about the role that technology should play in the training of translators and how it can be best oriented and applied (Rodríguez Inés, 2013; Doherty and Kenny, 2014; Wang, 2013; Rico, 2017a; Mellinger, 2017; Plaza Lara, 2019). In this connection, technology (or more specifically, technical and instrumental subcompetence) constitutes one of the core components of most translator competence models (PACTE, 2018) and needs to be

\footnotetext{
${ }^{1}$ This piece of research is framed in the DITAPE Research Project (2021/GV/080).
} 
revisited constantly, as evolution and technological progress affects not only the texts themselves and their accessibility, but also tools and resources optimizing human intervention.

Translation technology has traditionally been conceived as an instrumental competence and taught on specific courses in the translation curriculum. However, the translation multicomponential competence models that have dominated the scene do not seem to account for this new change of paradigm (Rozmyslowicz, 2014). Austermühl (2013) suggests two metacompetences: the capacity to review texts in the target language and the capacity for documentary research. Other compact proposals based on technological skills (Pym, 2013) have been put forward. The new European Masters in Translation (EMT) Competence Framework (EMT, 2017: 9) sets out that students should know how to:

- use the most relevant IT applications, including the full range of office soft-ware, an adapt rapidly to new tools and IT resources;

- make effective use of search engines, corpus-based tools, text analysis tools and CAT tools;

- pre-process, process and manage files and other media/sources as part of the translation, e.g., video and multimedia files, handle web technologies;

- master the basics of MT and its impact on the translation process;

- assess the relevance of MT systems in a translation workflow and implement the appropriate MT system where relevant; apply other tools in support of language and translation technology, such as workflow management software.

When incorporating technology in the translation classroom, one possible strategy that can be adopted is the holistic approach, which "seeks to integrate tool use across different elements of the programme" (Bowker and Marshman, 2010: 199). This can be implemented in technology courses, in practical translation or other courses, and as part of independent study activities. This way, students will become more familiar with technology and will use it more often in their translation exercises (Mellinger, 2017). These proposals should include innovative ideas for incorporating MT across the translation curriculum, since stand-alone courses on translation technologies seem to be insufficient to prepare students, "as language professionals are involved in multiple stages of MT implementation: terminology management, pre-editing and post-editing content, and recommending changes to MT service providers" (ibid., 2017: 290). Other recent studies in MT experiences involving statistical machine translation report that it is still necessary to incorporate it intensively in stand-alone courses (Kenny and Doherty, 2014; Doherty and Kenny, 2014; Rossi, 2017). All in all, new training experiences are trying to cover a wide range of translation technology including MT (Shuttleworth, 2017) and it seems that there is a clear trend towards greater uptake and professionalisation of tools and technologies training (Rothwell and Svoboda, 2019).

As to the methodologies used, student-centered approaches have taken central stage (Kiraly, 2000; González Davies, 2004; Kelly, 2005). Translator training, previously focused on learning to translate by translating, has evolved towards more pedagogical approaches by which scholars have proposed training models simulating professional practice to develop translator competences (Alcina et al., 2007). Accordingly, various authors 
advocate for the simulation of real collaborative projects in the learning of translation technology from a situational point of view (González Davies and Enríquez Raído, 2016; Killman, 2018; Mellinger, 2018). Other authors have suggested the use of the Portfolio (Calvo, 2017; Rico, 2017a), which in turn serves as a tool for student's empowerment. Samson (2013) agrees that the acquisition of general technology skills is necessarily associated with the use of appropriate IT tools to develop projects and solve problems in professional situations. Overall, it seems that there is consensus among scholars that translation programmes and curricula must be adjusted to the needs of the market by incorporating MT in a broad range of situations (Gaspari, Almaghout, and Doherty, 2015) that should inevitably include the new role of translator as MT posteditor (Rico and Torrejón, 2012; Sánchez-Gijón, 2016).

In any case, teaching third-level students about translation technology "is complicated by the dynamic technological environment, with standard practices regularly overridden by new and updated tools and technologies" (Moorkens, 2018: 375), so it is vital to build a cutting-edge technology teaching strategy when designing translation curricula. Another related and prominent constraint is the various challenges faced by translation trainers, who must help students in acquiring a sound technological competence that both fulfils the needs of the current language services industry and the new realities of higher education (Wu et al., 2019; Orlando, 2019).

\section{The Teaching Experiment}

\subsection{Philosophy and Goals}

The teaching practices of this experiment are based on the assumption that technology constitutes a fundamental part of the translation process. On the one hand, I contend that translation technology should not be taught as an isolated content or course. Quite the reverse, technology helps improving the translation process and, therefore, it should pervade the translation curriculum and be implemented intensively. On the other hand, MT is essentially a collaborative activity involving TM, corpora and other technological resources that have been created by other translators and linguists, so it is also essential to understand the benefits and constraints (as well as the limits) that MT entails. Another key aspect to consider is the market, as the translator's relocation in the translation supply chain has incorporated new phases, steps and agents. Thus, "the challenges of adopting MT as a professional tool are inevitably modulated by the degree to which different professional constituencies can influence how MT is implemented, managed and used" (Vieira and Alonso, 2020: 164).

With this focus in mind, a teaching experiment was conducted in October 2019 in the Degree of Translation and Interlinguistic Mediation at the Universitat de València to incorporate MT and PE techniques and procedures consistent with the professional demands of the market. On the educational side, the main goals were the following: 
- Make students aware of technological tools and resources available for translation: databases, translation memories, glossaries, MT tools (rule-based, statistic and neural MT translation engines) and PE tools.

- Evaluate the quality of the text translated by the machine in an objective and flexible way according to the requirements agreed with the client.

- To develop in the students a realistic perception about the postediting effort and its emotional dimension.

- Make students aware of the need to maintain the highest possible degree of control over the translation processes of their translation projects or orders involving MT and PE.

- Reflect and encourage debate about the concerns generated by the use of MT and its professional aspects, such as the confidentiality of the texts that are uploaded to a MT system or the price that should be charged for this type of work.

- Work on the perspective of communication and negotiation with the client to convey the importance of the human factor when using MT, either by post-editing the texts or training a particular engine, checking the terminological coherence of the text or establishing the quality of the final text.

\subsection{Setting and Participants}

The experiment targeted seventy Spanish undergraduate students from four translation courses within the Degree in Translation and Interlinguistic Mediation, a four-year program of the Universitat de València providing compulsory multilingual training in at least two foreign languages. During the first two years, students receive intensive training in foreign and mother languages as well as introductory general translation courses. As far as technology is concerned, students take part in the course Translation Technologies, an obligatory semester course of 6 ECTS. This course offers training in basic computer operations, operating systems, Internet tools and editing techniques to an advanced level. An introduction to CAT Tools is included, as well as the gathering and analysis of corpora, the creation and management of resources as well as technical terminology and translation tools. No mention has been found to MT and/or PE practices, nor to the integration of different MT/TM systems at the time of writing this paper. Two other related courses, Documentation for Translators and Terminology and Lexicography are also included in the syllabus.

All of the courses that were selected for the experiment are obligatory courses in the syllabus. They are of very different nature, ranging from specialized translation, e.g. scientific and economic translation texts (Specialized Translation 2, English-Spanish) and literary and audiovisual texts (Specialized Translation 3 English-Spanish) to general translation (Reverse Translation Spanish-English, General Translation 1, English-Spanish). The activities were designed by a group of translation trainers who previously attended a 12-hour course of basic training in MT and PE organized by the Universitat de València.

\subsection{Classroom activities}

Classroom activities designed by the trainers' team included the following: 
- Practices with different MT engines and tools. This included the comparison and error analysis of MT output.

- Postediting practices, including the implementation of techniques for light and full postediting.

- MT evaluation practices (manual and automatic).

- Information search, reflection, and debate activities about MT professional issues: confidentiality, market common practices, ethical aspects, pricing policies.

Students had to i) read a wide range of texts and recommended bibliography, ii) carry out a series of assignments in relation to the various topics or MT tools covered in class and iii) actively participate in class and be involved in their own learning experience and progress. Language pair used was English-Spanish, for which MT systems generally provide quality translations, as they have vast quantities of resources.

Following previous experiences (Doherty and Kenny, 2014), both theoretical and practical contents were introduced in the classroom. As for the type of technology used, free software was chosen, since professional translators use free online translation systems to a greater or lesser extent. Also, their open and transparent nature allows students to easily take control of the tools (Díaz Fouces, 2011). The selected MT and PE tools include rule-based, statistical and neural MT engines such as Apertium, Systran, DeepL, Google, Translate2018, as well as CAT Tools like MemSource or MateCat. These engines and tools have been fully tested and are commonly used by professional translators and PE specialists.

\section{Method}

According to previous similar research ( $\mathrm{Li}$ et al., 2015), a qualitative approach based on the methods of thematic and grounded theory analysis was used to research students' perceptions and attitudes. Grounded theory (Birks and Mills, 2015) has been long used and proved valid by teachers, academics and practitioners within various fields of Higher Education (Lichtman, 2013; Den Outer, Handley and Price, 2013). More specifically, this method has been incorporated in the field of applied linguistics to better understand the behaviour of their learners and gain insight into teaching and educational issues (Hadley, 2017).

Respondents completed both a preliminary and a final questionnaire (see full list of questions in the Appendix). Informed consent was obtained before completing the questionnaire for the use of the collected data for research purposes. Self-administered surveys were used, as this format presented a clear advantage, as it was possible to both collect a great amount of information and offer respondents more time to complete the survey and control the pace at which they did so, making it easier and more convenient for them to respond. Respondents answered without the aid of an interviewer, so as not to inject any bias in the questions that were asked. As for the questionnaire design, it included mainly open-ended questions, so that participants could answer in their own terms. Similarly, the use of open-ended questions allowed collecting possible replies that a close-ended questionnaire may not have contemplated, as open-ended schemes do not suggest fixed answers. This type of research tool proved to be useful 
to explore the importance of issues for respondents, even if it required a greater effort from them, who had to write extensively. Questions were drawn up for the express purpose of getting responses to the following research questions: (1) What are students' attitudes and perceptions towards MT? (2) To what extent students adopt MT and technology tools and resources? and (3) In what way can MT help to improve translation? These three questions are relevant for the research of MT didactics, as, despite the relative wealth of translation studies literature on translator training and translation technology, there seems to be a relative lack of research giving voice to undergraduate students and taking the issue of the incorporation of MT from the translation training perspective. It is also still unclear, to the present date, what for and to what extent translation students resort to MT and other translation technology tools and resources for their classroom work (Man et al., 2019).

Manual theme coding was conducted on the ground that manual analysis processes are entirely appropriate for small-scale projects (Saldaña, 2015). Once all the answers were collected, they were initially organised so that axial coding could be easily conducted. Each open-ended question entailed a careful and reflexive reading through answers before the coding. The initial step was to read and re-read the questionnaires to get a sense of the whole, i.e., to gain a general understanding of what the participants were talking about. At this point, the main points expressed by participants were grasped. The coding started with an initial open coding of relevant portions of text to capture data related to the research question. Second, an axial coding was set. This second step explored the relationship of categories, making connections between them and trying to pick up central codes to establish main code categories with a view to forming more precise and complete explanations. A third step consisted in reducing codes to themes by searching common elements in codes and producing a discoursive set of theoretical propositions by connecting the categories, thus building a set of research outcomes. This thematic analysis based on the content provided by the respondents, though fairly time-consuming, not only allowed for the examination of possible links between concepts to draw inferences, but also for the identification of their suitability in connection with our research aims. The resulting themes are reported and discussed in the following section.

\section{Results and discussion}

Previous research about attitudes to MT has focused mainly on professional translators and their views (Cadwell et al. 2017; Guerberof, 2013). Studies report translators' views on MT and PE to be mostly negative, especially among more experienced professionals (Moorkens and O'Brien, 2015; Läubli and Orrego Carmona, 2017; Rossi and Chevrot, 2019). More specifically, research has been conducted to explain why translators resist post-editing, "as they feel their professional skills and identities are sidelined by technology" (Sakamoto, 2019: 201). However, Vieira (2020) found that negative attitudes to MT in professional communities are usually more directly linked to business issues and the impact of technology on the market rather than to the notion that MT may outperform human translators. Most recent research has aimed at comparing different 
stakeholder perspectives on MT. In particular, Vieira and Alonso (2020) compared the views of translators with those stakeholders in management and production. Other studies explore translators' attitudes towards Translation-Computer Interaction in the form of MTassisted TM translation (Bundgaard, 2017). Finally, Doherty and Moorkens (2013) and, more recently, González Pastor and Rico (2021) have previously addressed students' perceptions towards MT.

Results reported in this paper include a sample size of twenty-two undergraduate students (96\% women) with ages ranging from 18 to 23 without previous training nor professional experience in MT. This group of students were trained with MT and PE in the course Specialised Translation 2. The training addressed theory and practice and included different assignments such as the comparison of different MT engines (SMT, NMT) and the comparison and analysis of MT output, the full postediting of a text (including MT quality evaluation using automatic metrics). It also tackled the issue of ethical implications of the use of MT in the professional setting.

Three main topics emerged from the thematic analysis that represent the participants' viewpoint towards MT: benefits and drawbacks associated with MT, knowledge and use of MT by students and related professional aspects.

\subsection{Benefits and drawbacks}

Results from the study show both positive and negative views, as respondents equally weight up benefits and potential perils from the use of MT (R14: "MT can help as long as the translator is still needed to postedit a text, but it would be negative if MT replaces completely the role of the translator" ${ }^{2}$ ).

This is in line with previous studies in various teaching contexts drawing both positive and negative attitudes and beliefs when using MT. In the Arabic context, Sahin (2015) concluded that the main reason for his novice translator's negative general attitude towards MT was the low quality of Google Translator output, although a positive change in student's attitudes was reported in student's thoughts about PE productivity after receiving training. All respondents (22) believe that MT can help them to translate under certain conditions (R2: MT can be a valuable tool when used appropriately ") and point at productivity as the most important advantage (R5: "MT saves time, speeds up work").

A common negative consideration towards MT by respondents is supported by the fact that MT does not seem to be valid for certain types of texts. This finding is in line from results reported from Cadwell et al. (2017), who found that the decision to use MT or not depended strongly on the type of text to be translated and on the language pair in question. Overall, negative attitudes regarding the use of MT change significantly once students receive training on MT and PE (Sukkwan, 2014; Rossi, 2017; Çetiner and işisağ, 2019) and are taught about the pros and cons of using MT (Alotaibi, 2014). In addition, students feel more confident and avoided over-editing (Stasimioti and Sononi, 2019).

\footnotetext{
${ }^{2}$ Respondents' transcripts, originally in Spanish, have been translated into English.
} 


\subsection{Knowledge and use of MT}

As to knowledge and adoption of technology tools, students were asked about what kind of tools they were acquainted with in the preliminary questionnaire. Answers refer to multiple resources: online dictionaries and glossaries, terminology databases, CAT and some TM/MT tools such as OmegaT, Google Translate, DeepL, Wordfast or DéjàVu, among other tools. However, they reported to actually use a far more limited catalogue of resources than the ones they know, and mentioned mainly online dictionaries such as Wordreference, Linguee and a very limited use of CAT tools and MT engines. In this sense, even if familiarity with translation technologies resulting in a frequency of use and a promotion of future adoption by translation students seems to be out of question (Man et al., 2019), it should be noted that translation courses in the curriculum may tend to place more emphasis on certain tools and resources than others.

Respondents also reported to use or have used MT tools at some time in order to complete their classroom translation assignments. When asked about the different applications when using MT, respondents offered detailed account of the various uses of MT. A large number of respondents (16) reported to resort to MT as a problemsolving tool when faced with text fragments containing especially difficult sentences or complex syntactic structures. Thus, students perceive MT as an advantageous tool when translating certain text types, namely scientific, technical, and economic and allude to the fact that they contain repetitive terminology and syntax that MT can translate fairly well ("R11: sometimes technical texts contain unknown terminology and complex sentences that MT can solve"), although PE is deemed necessary to refine MT output. 6 respondents also refer to the fact that certain textual features are preserved by NMT ("R7: some specialised texts are repetitive, so if neural translation engines are used, the style marked by the genre is already applied"). This correlates with Witczak's findings (2016), whose students felt that formulaic texts were most convenient for PE. Another interesting finding is the fact that some students rely on MT to compare their translations with the MT output or even use it to assess their own translations (R15: "It helps me to compare and check if I have done my translation correctly"). In general, when used for different purposes other than translation, MT is used to grasp the overall meaning and content of a text of a language students are not familiar with and as an assistance tool when learning a new language.

\subsection{Professional aspects}

Perceptions on how MT will affect the translation professional scenario are also both positive and negative. Students view MT as a "double-edged sword" (R18): just as it becomes a professional help for the translator by speeding up work, it is also beneficial for the client, who may rely less and less on the translators' work (R11: "if a client wants MT and may not care about the final quality of the product, this will also be very harmful to the sector in a certain way").

The shift in the translator's role is a common preoccupation of respondents. On the whole, students envisage that the development of MT will bring about new changes in the role of translator towards a posteditor profile (R2: "In the future, we, translators, will 
be more like reviewers than actual translators"), thus accommodating the industry needs. In this connection, respondents mention the fact that, despite the advancement of technology, MT will not be able to replace human translators (R19: "The role of the translator will not disappear in creative areas such as literary or advertising translation. Nor will it replace the interpreters"). Some respondents foresee that translators will also play a part in the configuration and refinement of MT systems (R9: "I think that the profession of translator will help in the future to program the machines that will perform the translations"). Respondents' preoccupation is also brought up in different professional situations involving the use of confidential data, the final price that must be charged, as well as other ethical issues.

\section{Conclusions}

Technologisation has become part and parcel of professional translation in an evolving industry landscape in which new disruptive tools as MT have come to stay. This is reshaping the workflow and the professional role of the translator developing towards quality control and specialising on PE (Bawa-Mason, 2018). In light of these changes, translation scholars and trainers are discussing the need to train novice translators toward becoming language-services advisors (Melby and Hague, 2020) and specialise in the new translation profiles emerging from this age of MT.

Since the learning of this technology still plays a marginal role in many translation programmes in Spain (Cid-Leal, Espín-García and Presas, 2019), an experiment to introduce MT in the translation classroom in several courses from the degree in Translation and Interlinguistic Mediation has been carried out at the Universitat de València in Spain. As opposed to traditional teaching practices, which included technology in independent courses where tools were practiced in isolation, a change of focus is needed in order to embed MT into the translation curriculum from a wider perspective (Mellinger, 2017). The survey, focusing on the Spanish context, strived at mapping student's attitudes and perceptions towards MT. Findings of a thematic analysis reveal three main topics: benefits and drawbacks associated with MT, knowledge and use of MT by students and related professional aspects. Undergraduate students show general positive attitude towards MT after the training and the completion of activities, which were positively assessed by respondents. Generally, translation students view MT as a versatile tool that can be helpful for multiple purposes. Findings also revealed widespread preoccupation among students about how technology and MT affects professional work, so putting the focus on how technology affects working conditions, pay and professional self-image should be one key issue when introducing MT in the translation classroom. As to MT adoption, most students reported to have used MT on their own motion at some time for their classroom translation assignments and express their willingness to receive further training in MT and other technology translation tools. Overall, findings promote the incorporation of technology and MT in particular into the translation classroom in order to enhance students' skills and maximize their employability opportunities in the current high-speed changing translation market whilst the teaching 
experiment has been proved valuable to raise awareness of MT capabilities and shortcomings among students.

This study presents some limitations that should be addressed in the future. As it is an exploratory small-scale study focused on a specific context, it will be necessary to conduct further research of a greater dimension and scope. This piece of research contributes to the incipient research of how undergraduate students see the incorporation of MT in their translation courses and results help shedding some light into the factors influencing the design of an innovative translation training curriculum.

\section{References}

Alcina, Amparo; Soler, Victoria; Granell, Joaquín (2007). Translation technology skills acquisition. Perspectives. Studies in Translation Theory and Practice, v. 5, n. 4, pp. 230-244. 〈https://doi.org/10.1080/13670050802280179〉. [Accessed: 20211223].

Alotaibi, Hind M. (2014). Teaching CAT Tools to Translation Students: An Examination of Their Expectations and Attitudes. Arab World English Journal, v. 3, n. 1, pp. 6574. 〈https://www.awej.org/images/Allssues/Specialissues/Translation3/6.pdf〉. [Accessed: 20211223].

Álvarez Vidal, Sergi; Oliver, Antoni; Badia, Toni (2020). Post-editing for Professional Translators: Cheer or Fear? Revista Tradumàtica: tecnologies de la traducció, n. 18, pp. 49-69. 〈https://doi.org/10.5565/rev/tradumatica.275〉. [Accessed: 20211223].

Austermühl, Frank (2013). Future (and not so future) trends in the teaching of translation technology. Revista Tradumàtica: tecnologies de la traducció, n. 10, pp. 326-337. 〈https://doi.org/10.5565/rev/tradumatica.46〉. [Accessed: 20211223].

Bawa-Mason, Sarah (2018). The Translation Sector of the Future: Indications from the FIT 2017 Conference. Disruption and Diversification. Revista Tradumàtica: tecnologies de la traducció, n. 16, pp. 71-84. 〈https://doi.org/10.5565/rev/tradumatica.213〉. [Accessed: 20211223].

Birks, Melanie; Mills, Jane (2015). Grounded Theory: A Practical Guide. Singapore: Sage Publications.

Bowker, Lynne; Marshman, Elizabeth (2010). Toward a Model of Active and Situated Learning in the Teaching of Computer-Aided Translation: Introducing the Collection of Electronic Resources in Translation Technologies Project (CERTT). Journal of Translation Studies, v. 13, n. 1\&2, pp. 199-226.

Bundgaard, Kristine (2017). Translator Attitudes towards Translator-Computer Interaction. Findings from a Workplace Study. Hermes: Journal of Language and Communication in Business, n. 56, pp. 125-144. 〈https://doi.org/10.7146/hjlcb.v0i56.97228〉.

[Accessed: 20211223].

Cadwell, Patrick; O’Brien, Sharon; Teixeira, Carlos S. C. (2017). Resistance and accommodation: factors for the (non)-adoption of machine translation among professional translators. Perspectives: Studies in Translation Theory and Practice, v. 
26, n. 3, pp. 301-321. 〈https://doi.org/10.1080/0907676X.2017.1337210〉. [Accessed: 20211223].

Calvo, Elisa (2017). Servicios de valor añadido en contextos situacionales en Traducción: de los proyectos al portafolio. RIDU: Revista Digital de Investigación en Docencia Universitaria, v. 11, n. 2, pp. 136-154. 〈https://doi.org/10.19083/ridu.11.576〉. [Accessed: 20211223].

Çetiner, Caner; işisağ, Korkut Uluç (2019). Undergraduate Level Translation Students' Attitudes towards Machine Translation Post-Editing Training. International Journal of Languages' Education and Teaching, v. 7, n. 1, pp. 110-120. 〈https://doi.org/10.18298/ijlet.3242〉. [Accessed: 20211223].

Cid-Leal, Pilar; Espín-García, María-Carmen; Presas, Marisa (2019). Traducción automática y posedición: perfiles y competencias en los programas de formación de traductores. MonTI: Monografias de Traducción e Interpretación, n. 11 (eds. M. Tolosa Igualada; A. Echeverri. Porque algo tiene que cambiar...), pp. 187-214. $\langle$ https://doi.org/10.6-035/MonTI.2019.11.7〉. [Accessed: 20211223].

Den Outer, Birgit; Handley, Karen; Price, Margaret (2013). Situational analysis and mapping for use in education research: a reflexive methodology? Studies in Higher Education, v. 38, n. 10, pp. 1504-1521. 〈https://doi.org/10.1080/03075079.2011.641527〉. [Accessed: 20211223].

DePalma, D. A.; Pielmeier, H.; Stewart, R.G; Henderson, S. (2016). The Language Services Market: 2016. Common Sense Advisory.

Díaz Fouces, Oscar (2011). ¿Merece la pena introducir el software libre en la formación de traductores profesionales? Language and Translation Teaching in Face-to-Face and Distance Learning, n. 8, pp. 1-22.

Díaz Fouces, Oscar (2019). Algunas consideraciones sobre el papel de las tecnologías en los Estudios de Traducción y la formación de traductores. Hikma, v. 18, n. 1, pp. 57-84. http://hdl.handle.net/10396/19473>. [Accessed: 20211223].

Do Carmo, Félix (2020). Time is money and the value of translation. Translation Spaces, v. 9, n.1, pp. 35-57. 〈https://doi.org/10.1075/ts.00020.car〉. [Accessed: 20211223].

Doherty, Stephen; Kenny, Dorothy (2014). The design and evaluation of a Statistical Machine Translation syllabus for translation students. The Interpreter and Translator Trainer, v. 8, n. 2, pp. 295-315. 〈https://doi.org/10.1080/1750399X.2014.937571〉. [Accessed: 20211223].

Doherty, Stephen; Moorkens, Joss (2013). Investigating the Experience of Translation Technology Labs: Pedagogical Implications. The Journal of Specialised Translation, n. 19, pp. 122-136. 〈https://www.jostrans.org/issue19/art_doherty.pdf). [Accessed: 20211223]. 
European Masters in Translation. (2017). European Masters in Translation competence framework 2017. 〈https://ec.europa.eu/info/sites/info/files/emt_competence_fwk_2017_en_web.pdf). [Accessed: 20200730].

Gambier, Yves (2014). Changing landscape in translation. International Journal of Society, Culture and Language, v. 2, n. 2, pp. 2-12. 〈http://www.ijscl.net/article_4638_8301154b3bfe303a6e1c541f62c4e18a.pdf〉. [Accessed: 20211223].

Gaspari, Federico; Almaghout, Hala; Doherty, Stephen. (2015). A survey of machine translation competences: Insights for translation technology educators and practitioners. Perspectives: Studies in Translatology, v. 23, n. 3, pp. 333-358. 〈https://doi.org/10.1080/0907676X.2014.979842〉. [Accessed: 20211223].

González Davies, Maria. (2004). Multiple Voices in the Translation Classroom: activities, tasks and projects. Amsterdam; Philadelphia: John Benjamins. (Benjamins translation library; 54).

González Davies, Maria; Enríquez Raído, Vanessa. (2016). Situated learning in translator and interpreter training: bridging research and good practice. The Interpreter and Translator Trainer, v, 10, n. 1, pp. 1-11. 〈https://doi.org/10.1080/1750399X.2016.1154339〉. [Accessed: 20211223].

González Pastor, Diana; Rico, Celia (2021). POSEDITrad: la traducción automática y la posedición para la formación de traductores e intérpretes. RIDU: Revista Digital De Investigación en Docencia Universitaria, v. 15, n. 1, e1213. 〈https://doi.org/10.19083/10.19083/ridu.2021.1213〉. [Accessed: 20211223].

Guerberof Arenas, A. (2013). What do professional translators think about post-editing? JosTrans, The Journal of Specialised Translation, n. 19, pp. 75-95. 〈https://www.jostrans.org/issue19/art_guerberof.pdf). [Accessed: 20211223].

Hadley, Gregory (2017). Grounded Theory in Applied Linguistics Research: A Practical Guide. Milton Park, Abingdon, Oxon; New York, NY: Routledge. (routledge studies in applied linguistics; 1).

Kelly, Dorothy Anne. (2005). A Handbook for translator trainers: A guide to reflective practice. Manchester, Mass: St. Jerome. (Translation practices explained; 10).

Kenny, D.; Doherty, S. (2014). Statistical Machine Translation in the Translation Curriculum: Overcoming Obstacles and Empowering Translators. The Interpreter and Translator Trainer, v. 8, n. 2, pp. 276-294. 〈https://doi.org/10.1080/1750399X.2014.936112〉. [Accessed: 20211223].

Killman, J. (2018). A context-based approach to introducing translation memory in translator train-ing. In: Godev, C. B. (ed.). Translation, globalization and translocation. Cham, Switzer-land: Palgrave Macmillan, pp. 137-159.

Kiraly, Donald C. (2000). A Social Constructivist Approach to Translator Education. Empowerment from Theory to Practice. Manchester: St. Jerome. 
Koponen, Maarit (2016). Is machine translation post-editing worth the effort? A survey of research into post-editing and effort. JoSTrans: The Journal of Specialised Translation, n. 25, pp. 131-148. 〈https://www.jostrans.org/issue25/art_koponen.pdf〉. [Accessed: 20211223].

Läubli, S.; Orrego-Carmona, D. (2017). When Google translate is better than some human Colleagues, those people are no longer colleagues. In: Proceedings of the 39th Conference Translating and the Computer, London, UK, November 16-17. AsLing, pp. 59-69.

LeBlanc, M. (2017). I can't get no satisfaction: Should we blame translation technologies or shift business practices? In: Kenny, Dorothy (ed). Human Issues in Translation Technologies. London; New York: Routledge, pp. 45-62.

Leiva Rojo, J. (2018). Aspects of human translation: the current situation and an emerging trend. Hermeneus: revista de traducción e intepretación, n. 20, pp. 257294. 〈https://doi.org/10.24197/her.20.2018.257-294〉. [Accessed: 20211223].

Li, Defeng; Zhang, Chunling; Yuanjian, He. (2015). Project-based learning in translation: student's perceptions. The Interpreter and Translator Trainer, v. 9, n. 1, pp. 1-19. 〈https://doi.org/10.108-0/1750399X.2015.1010357〉. [Accessed: 20211223].

Lichtman, Marilyn (ed.) (2013). Understanding and evaluating qualitative educational research. Los Angeles, CA: Sage Publications.

Man, Deliang; Mo, Aiping; Chau, Meng Huat; O’Toole, John Mitchell; Lee, Clarity (2019). Translation Technology Adoption: Evidence from a Post-graduate programme for student translators in China. Perspectives: Studiesin Translation Theory and Practice, v. 28, n. 2, pp. 256-270. 〈https://doi.org/10.1080/0907676X.2019.1677730〉. [Accessed: 20211223].

Melby, A. K.; Hague, D.R. (2020). A singular(ity) preoccupation: Helping translation students become language-services advisors in the age of machine translation. In: Sawyer, D. B.; Austermühl, F.; Enríquez Raído, V. (eds). The evolving curriculum in interpreter and translator education: stakeholder perspectives and voices. Amsterda; Philadelphia: John Benjamins, pp. 204-227.

Mellinger, Christopher D. (2017). Translators and machine translation: knowledge and skills gaps in translator pedagogy. The Interpreter and Translator Trainer, v. 11, n. 4, pp. 280-293. 〈https://doi.org/10.1080/1750399X.2017.1359760〉. [Accessed: 20211223].

Mellinger, Christopher D. (2018). Problem-based learning in computer-assisted translation pedagogy. Hermes: Journal of Language and communication in Business, n. 57, pp. 195-208. 〈https://doi.org/10.7146/hjlcb.v0i57.106205〉. [Accessed: 20211223].

Moorkens, Joss; O’Brien, Sharon (2015). Post-editing evaluations: Trade-offs between novice and professional participants. El-Kahlout, I. D.; et al. (eds). Proceedings of the 18th Annual Conference of the European Association for machine translation (EAMT) 2015. Antalya: European Association for Machine Translation, pp. 75-81. 
Moorkens, Joss (2018). What to expect from Neural Machine Translation: a practical inclass translation evaluation exercise. The Interpreter and Translator Trainer, v. 12, n. 4, pp. 375-387. 〈https://doi.org/10.1080/1750399X.2018.1501639〉. [Accessed: 20211223].

Olohan, M. (2019). Sociological approaches to translation technology. In: O'Hagan, Minako (ed.). The Routledge Handbook of Translation and Technology. Abingdon, Oxon; New York, NY: Routledge. (routledge handbooks in translation and interpreting), pp. 384-397.

Orlando, Marc (2019). Training and educating interpreter and translator trainers as practitioners-researchers-teachers. The Interpreter and Translator Trainer, v. 13, n. 3, pp. 216-232. 〈https://doi.org/10.1080/1750399X.2019.1656407〉. [Accessed: 20211223].

PACTE (2018). Competence levels in translation: Working towards a European framework. The Interpreter and Translator Trainer, v. 12, n. 2, pp. 111-131. 〈https://doi.org/10.1080/1750399X.2018.1466093〉. [Accessed: 20211223].

Pielmeier, Hélène; O’Mara, Paul Daniel. (2020). The State of the Linguist Supply Chain: Translators and Intepreters in 2020. CSA Research. 〈https://insights.csaresearch.com/reportaction/305013106/Toc〉. [Accessed: 20200720].

Plaza Lara, C. (2019). Análisis DAFO sobre la inclusión de la traducción automática y la posedición en los másteres de la red EMT. JoSTrans: The Journal of Specialised Translation, n. 31, pp. 260-280. 〈https://www.jostrans.org/issue31/art_plaza.pdf). [Accessed: 20211223].

Pym, Anthony (2011). What technology does to translating. The International Journal for Translation and Interpreting, v. 3, n. 1, pp. 2-9. 〈http://www.transint.org/index.php/transint/article/viewFile/121/81〉. [Accessed: 20211223].

Pym, Anthony. (2013). Translation Skill-Sets in a Machine-Translation Age. Méta: Journal des Traducteurs $=$ Translators Journal, v. 58, n. 3, pp. 487-503. 〈https://doi.org/10.7202/1025047ar〉. [Accessed: 20211223].

Rico, Celia; Torrejón, Enrique (2012). Skills and Profile of the New Role of the Translator as MT Post-editor. Tradumàtica: Tecnologies de la Traducció, n. 10, pp. 166-178. 〈https://revistes.uab.cat/tradumatica/article/view/n10-torrejon-rico/pdf〉. [Accessed: 20211223].

Rico, Celia (2017a). The ePortfolio: constructing learning in translation technology. The Interpreter and Translator Trainer, v. 11, n. 1, pp. 79-95. 〈https://doi.org/10.1080/1750399X.2017.1306995〉. [Accessed: 20211223].

Rico, Celia (2017b). La formación de traductores en traducción automática. Tradumàtica: Tecnologies de la Traducció, n. 15, pp. 75-96. $\langle$ https://doi.org/10.5565/rev/tradumatica.200〉. [Accessed: 20211223].

Rodríguez-Inés, Patricia (2013). Electronic target-language specialised corpora in translator educa-tion: Building and searching strategies. Babel, v. 59, n. 1, pp. 57-75. 
Rossi, Caroline (2017). Introducing statistical machine translation in translator training: from uses and perceptions to course design, and back again. Tradumàtica: Tecnologies de la Traducció, n. 15, pp. 48-62. $\langle$ https://doi.org/10.5565/rev/tradumatica.195〉. [Accessed: 20211223].

Rossi, Caroline; Chevrot, Jean Pierre (2019). Uses and perceptions of machine translation at the European Commission. The Journal of Specialised Translation, n. 31, pp. 177-300. 〈https://jostrans.org/issue31/art_rossi.pdf〉. [Accessed: 20211223].

Rothwell, Andrew; Svoboda, Tomás (2019). Tracking translator training in tools and technologies: findings of the EMT survey 2017. JoSTrans: The Journal of Specialised Translation, n. 32, pp. 26-60 〈https://jostrans.org/issue32/art_rothwell.php〉. [Accessed: 20211223].

Rozmyslowicz, T. (2014). Machine Translation: A Problem for Translation Theory. New Voices in Translation Studies, v. 11, n. 1, pp. 145-163.

Şahin, M. (2015). Machine Translation and Computer-Aided Translation for English Turkish from the Viewpoint of Prospective Translators: The Google Experiment. Hacettepe University Journal of Translation Studies, n. 21, pp. 43-60.

Sakamoto, Akiko (2019). Why do many translators resist post-editing? A sociological analysis using Bourdieu's concepts. The Journal of Specialised Translation, n. 31, pp. 201-216. 〈https://jostrans.org/issue31/art_sakamoto.pdf〉. [Accessed: 20211223].

Saldaña, Johnny (2015). The Coding Manual for Qualitative Researchers. 3rd ed. Los Angeles; London: Sage.

Sánchez-Gijón, Pilar (2016). La posedición: hacia una definición competencial del perfil y una descripción multidimensional del fenómeno. Sendebar: revista de Traducción e Interpretación, n. 27, pp. 151-162. 〈https://revistaseug.ugr.es/index.php/sendebar/article/view/4016〉. [Accessed: 20211223].

Sánchez Torrón, Marina (2017). Productivity in post-editing and in neural interactive translation pre-diction: A study of English-to-Spanish professional translators. $\mathrm{PhD}$ thesis. University of Auckland, Auckland.

Samson, Richard (2013). El aprendizaje de las herramientas informáticas en la formación del traductor. Tradumàtica: Tecnologies de la Traducció, n. 11, pp. 247256. 〈https://doi.org/10.5565/rev/tradumatica.54〉. [Accessed: 20211223].

Shuttleworth, M. (2017). Cutting teeth on translation technology: How students at University College London are being trained to become tomorrow's translators. Tradução em Revista, n. 22, pp. 18-38. 〈https://doi.org/10.17771/PUCRio.TradRev.30595〉. [Accessed: 20211223].

Stasimioti, Maria; Sosoni, Vilelmini (2019). Undergraduate Translation Students' Performance and Attitude vis-àvis Machine Translation and Post-editing: Does Training Play a Role? In: Proceedings of the Translating and the Computer Conference 41, London 21-22 November 2019, pp. 125-136. 
〈https://www.asling.org/tc41/wp-content/uploads/TC41-Proceedings_125-136.pdf). [Accessed: 20200720].

Sukkhwan, Arissara (2014). Students' Attitudes and Behaviours towards the Use of Google Translate. Master Thesis. Prince of Songkla University, Thailand. 〈https://kb.psu.ac.th/psukb/bitstream/2010/9459/1/387714.pdf〉. [Accessed: 20211223].

Torres Hostench, Olga; Cid-Leal, Pilar; Presas, Marisa (coords.). (2016). El uso de traducción automática y posedición en las empresas de servicios lingüísticos españolas: informe de investigación ProjecTA 2015. Bellaterra. 〈https://ddd.uab.cat/record/148361〉. [Accessed: 20211223].

Vieira, Lucas Nunes (2020). Automation anxiety and translators. Translation Studies, v. 13, n. 6, pp. 1-21. 〈https://doi.org/10.1080/14781700.2018.1543613〉. [Accessed: 20211223].

Vieira, Lucas Nunes; Alonso, Elisa (2020). Translating perceptions and managing expectations: an analysis of management and production perspectives on machine translation. Perspectives: Studies in Translation Theory and Practice, v. 28, n. 2, pp. 163-184. 〈https://doi.org/10.1080/0907676X.2019.1646776〉. [Accessed: 20211223].

Wang, H. (2013). A constructive technology curriculum for MTI education from the perspective of language service industry technologies. Chinese Translators Journal, v. 34, n. 6, pp. 23-28.

Way, Andy (2018). Quality expectations of machine translation. In: Moorkens, J.; Castilho, S.; Gaspar, F.; Doherty, S. (eds.). Translation Quality Assessment: From Principles to Practice. Machine translation: technologies and applications. Cham: Springer International Publishing, pp. 159-178.

Witczak, Olga (2016). Incorporating post-editing into a computer-assisted translation course: A study of student attitudes. Journal of Translator Education and Translation Studies, v. 1, n. 1, pp. 33-55.

Wu, Di; Zhang, Lawrence Jun; Wei, Lan (2019). Developing translator competence: understanding trainers' beliefs and training practices. The Interpreter and Translator Training, v. 13, n. 3, pp. 233-254. 〈https://doi.org/10.1080/1750399X.2019.1656406〉. [Accessed: 20211223].

Zhechev, V. (2014). Analysing the post-editing of machine translation at Autodesk. In: O'Brien, Sharon; et al. (eds.). Post-editing of machine translation: Processes and Applications. Newcastle upon Tyne: Cambridge Scholars Publishing, pp. 2-24.

\section{APPENDIX}

\section{PRELIMINARY QUESTIONNAIRE}

1. Are you in your first, second, third or fourth year of degree?

2. From this list, indicate the subjects in which you have enrolled. 
3. Which translation tools do you know?

4. Which translation tools do you normally use and what for?

5. What do you understand by MT?

6. What do you understand by PE?

7. Have you received any previous training in MT and PE during your university studies?

8. Have you ever used MT to complete your class translation assignments?

9. What do you use MT for?

10. Do you have any professional experience using MT?

11. In what way do you think MT will affect the translator profession?

12. Do you think that your current knowledge of technology is enough to get along well in the professional setting? Why?

\section{FINAL QUESTIONNAIRE}

1. In which subject are you filling up this questionnaire? Choose only one option.

2. What do you think you have learnt about MT in this subject?

3. Do you think that MT can help you to better translate this course's assignments? In what way?

4. Do you think that MT helps you to make the translation of a specialised text? Why?

5. Is MT helpful when searching information and documentation in this course? Why?

6. For which types of texts would you use MT in this course?

7. Were MT activities designed and explained clearly and easy? Have you been provided the necessary materials and resources to complete all the activities?

8. Have the explanations and information received in this course been sufficient to complete the tasks required?

9. Were you able to solve all the doubts you had when completing the activities in this specific course?

10. Are there any other activities that you would have liked to do?

11. Do you think that using MT has an effect on the final price that is paid for a translation? Indicate briefly why.

12. Do you think that the use of MT has any connection with the confidential use of data?

13. Is there any ethical question related to the use of MT? In the classroom? In the labour market? Explain why.

14. When do you think that MT should be incorporated in the university program of Translation and Interpreting Studies? Why?

15. Do you think it is necessary to know how to handle human translation well before learning to use MT? Justify your answer.

16. Do you think that you should continue your training in MT? Justify your answer. 